\title{
Complementary and integrative practices in oral health: A Systematic Review
}

Práticas integrativas e complementares em saúde bucal: uma revisão sistemática
Camila da Silva GONÇALO

M.Sc - Ph.D - Student Faculty of Medical Sciences - UNICAMP University of Campinas - Campinas - Brazil

Nelson Filice de BARROS M.Sc. - Ph.D - Faculty of Medical Sciences - UNICAMP University of Campinas - Campinas - Brazil

\section{Abstract}

Objective: To present a systematic literature review on the use of Complementary and Integrative Practices (CIP) in the field of dentistry. Methods: Randomized, controlled clinical trials (RCT) were selected from the PubMedMEDLINE database (2000 - 2010). The articles were classified according to type of therapy, level of significance of results, impact factor, and area of knowledge of the periodicals. Results: Ninety-one RCTs were included: 43 (47\%) on Laser therapy, 31 (34\%) on Phytotherapy, 14 (16\%) on Acupuncture, 2 (2\%) on Homeopathy, and 1(1\%) on Hypnosis. The results showed negative evidences, particularly for Laser therapy $(\mathrm{n}=27 ; 30 \%)$, whereas Phytotherapy $(n=20 ; 22 \%)$, Acupuncture $(n=12 ; 13 \%)$ and Homeopathy $(\mathrm{n}=2 ; 2 \%)$ presented higher frequency of positive results. The RCTs researched were published in journals related to dentistry $(\mathrm{n}=59 ; 64 \%)$, medicine $(\mathrm{n}=$ $21 ; 23.5 \%)$, other areas $(n=7 ; 8 \%)$ and CIP $(n=4 ; 4.5 \%)$. Conclusions: It was concluded that there are positive evidences for the use of some types of CIP in oral health. However, they are limited as regards their quality and consistency, with little difference between the positive and negative results, characterizing little strength of evidence, and consequently low potential for clinical application in accordance with the principles of evidence-based dentistry.

\section{KEYWORDS}

Acupuncture; Homeopathy; Phytotherapy; Hypnosis; Flower therapy; Laser therapy.

\section{Resumo}

Objetivo: Apresentar uma revisão sistemática da literatura sobre a utilização de Práticas Integrativas e Complementares (PIC) na área da Odontologia. Métodos: Estudos Clínicos Controlados Randomizados (ECCR) foram selecionados na base de dados PUBMED (2000-2010). Os artigos foram classificados de acordo com o tipo de terapia, nível de significância dos resultados, fator de impacto e área de conhecimento dos periódicos. Resultados: Noventa e um ECCRs foram incluídos: 43 (47\%) sobre laserterapia; 31 (34\%) sobre fitoterapia; 14 (16\%) sobre acupuntura; 2 (2\%) sobre homeopatia e $1(1 \%)$ sobre hipnose. Os resultados mostraram evidências negativas especialmente para a laserterapia $(n=27 ; 30 \%)$; enquanto que maiores frequências de resultados positivos foram detectadas para a fitoterapia $(n=20 ; 22 \%)$, acupuntura $(n=12 ; 13 \%)$ e homeopatia $(\mathrm{n}=2 ; 2 \%)$. Os ECCRs foram publicados em periódicos de Odontologia $(\mathrm{n}=59 ; 64 \%)$, Medicina ( $\mathrm{n}$ $=21 ; 23,5 \%)$, outras áreas $(n=7 ; 8 \%)$ e PIC $(n=4 ; 4,5 \%)$. Conclusões: Conclui-se que há evidências positivas sobre a utilização de PIC em saúde bucal. Entretanto, as mesmas são limitadas em relação à qualidade e consistência, com pequena diferença entre resultados positivos e negativos. Este fato caracteriza pouca força de evidência e consequentemente baixo potencial para indicação clínica de acordo com os princípios da Odontologia baseada em evidências.

\section{Palavras-chave}

Acupuntura; Homeopatia; Fitoterapia; Hipnose; Terapia Floral;Terapia a Laser. 


\section{INTRODUCTION}

Acute and chronic diseases have increasingly been treated by means of Complementary and Integrative Practices (CIP). These practices have gained adepts all over the world and enabled the development of differentiated models of health care [1]. Based on the holistic perspective, generally CIP conceives disease as being a set of causes that culminates in imbalance or disharmony [2].

Extension in the use of these practices has occurred parallel to scientific and technological progress in health [3-6], and this contradiction has aroused the interest of users, researchers, professionals and health service managers [7]. The production of researches on CIP has increased considerably over the last few years, pointing out their benefits and including them in the universe of evidence-based practices [8].

The growing trend in the health area in establishing the validity of all diagnostic and therapeutic practices based on evidences derived from Randomized Controlled Clinical Trials (RCT) is also present in dentistry, creating the concept of Evidence-Based Dentistry (EBD). This concept was introduced to the scientific community over a decade ago $[9,10]$ and encompasses the conscious, explicit and judicious use of the best evidence available in conjunction with clinical experience and the patient's preference in taking decisions with reference to oral health care [11]. From the perspective of EBD, dentists must be capable of evaluating and understanding the level of evidence available and the effect of this information on the strength on which a clinical procedure may be recommended to the patient.

The development of EBD led to the techniques of systematic reviews of Randomized Controlled Clinical Trials (RCT) to being diversified and to gaining relevance. Thus, the growing number of Systematic Literature Reviews (SLR), at present considered references of the highest level of evidence [12-14] that offer important information on which to base the choice of the clinical procedure to be adopted [14].

In Brazil, in 2008, the Federal Council of Dentistry regulated six modalities of CIP for dental treatments. This decision was based on the recognition of CIP by the World Health Organization, on public policies of the addition of CIP, and on the dental code of ethics in force. The content of ethics in force states that "Dentistry is a profession performed for the benefit of the health of the human being and society without discrimination of any type or pretext, and that it is the dental surgeon's duty to keep up to date, the Professional technical, scientific and cultural knowledge necessary to exercise the profession at the full performance level" [15]. For this reason this SLR was performed, with the aim of identifying and analyzing scientific evidences on the use of Acupuncture, Homeopathy, Phytotherapy, Flower Therapy, Hypnosis and Laser therapy in dentistry.

\section{Methods}

Once the aim of this SLR had been defined, a systematic survey of the literature in PubMedMEDLINE was undertaken by two independent researchers. This data base was chosen due to the fact that it is the most important in the area of health and is consulted throughout the world [16-18].

We know that the definition of "old study" varies according to the medical specialties and according to different knowledge areas [19]. We also considered that studies written 5 - 10 years ago can provide researchers the opportunity to look at the historical context of the subject researched and provide guidance for later research [20]. For operational purposes, in this systematic review, the period established for the search of articles was from 2000 to 2010. The procedure was performed in three stages. In the first two stages, general surveys were made with a view to capturing the largest possible number of references related to the use of CIP in oral health. The inclusion criterion of CIP was based on Resolution 82/2008 of the Brazilian Federal Council of Dentistry (FCD), which has recognized the following therapies for clinical dental use in Brazil: Acupuncture, Homeopathy, Phytotherapy, Hypnosis, Flower Therapy and Laser Therapy [15].

Therefore, in the first two stages the Descriptors in Health Sciences (DeCS), created from the Medical Subject Headings (MeSH) of the U.S. National Library of Medicine (NLM) were used, which allowed the retrieval of bibliographic references in Portuguese, Spanish and English [21]. The descriptors used in the first stage of this SLR (April/2010) were: alternative therapy and dentistry. In the second stage (July/2010) the following descriptors were added: acupuncture; homeopathy; phytotherapy; hypnosis; flower therapy; laser therapy. The second survey was performed with the individual use of the descriptors as well as a combination of these.

In November, 2010 the third stage of the literature search was conducted by means of the following composition of key words: dental acupuncture; dental homeopathy; dental phytotherapy; dental flower therapy; dental hypnosis e dental laser therapy. A schematic 
illustration of the stages of the literature search in PubMed-MEDLINE may be observed in Figure 1.

In this SLR only Randomized Controlled Clinical Trials (RCT), identified as being "good evidence" by the ranking of evidences of interventions in health [22] and the American Dental Association [23] were included. The selected articles were read in full and classified in accordance with the CIP modality, level of significance of the results, impact factor and area of knowledge of the periodical in which they were published.

For classification of the level of significance of the results, the criteria proposed by Pittler et al. [24] were adopted, in which positive results are those that present statistically significant values $(\mathrm{p}<0.05)$ in favor of the studied CIP, when compared with the control group. When there were no statistically significant differences between the CIP intervention and the control group, or when the results were favorable to the control group, they were classified as negative results. Studies that did not precisely relate the levels of significance were classified according to the conclusion cited in the article. In the case of positive and negative outcomes stated in one and the same study, the result directly linked to the main objective of the study was considered.

The list of "Journal Citation Reports ${ }^{\circledR}$ by ISI Web of Knowledge" was consulted, in February 2011, to obtain the Impact Factors (IF) of the periodicals that published the articles included in this SLR. It was observed that the list available in the mentioned site was based on the year 2009 [25]. Afterwards, the website of each periodical was consulted according to the information available in the section "about journal", and these were classified according to their areas of knowledge, such as: dental, medical, specifically about CIP and other areas. In case of discrepancy in the inclusion and classification of the RCT, the researchers' decision by means of consensus prevailed.

\section{Results}

A total of 1616 references were identified, read and classified. After applying the inclusion criteria and eliminating the duplicates, 91 studies were included, which corresponded to $5.5 \%$ of the studied universe. Among the $91 \mathrm{RCT}$ selected on the use of CIP in dentistry, 43 (47\%) were about the use of Laser therapy; 31 (34\%) about Phytotherapy; 14 (16\%) about Acupuncture; 2 (2\%) about Homeopathy and $1(1 \%)$ about Hypnosis. No RCT about the use of Flower Therapy in the dental clinic was identified. The studies were separated according to type of CIP and were categorized as regards the type of evidence - positive or negative. Positive evidences were identified in 20 (22\%) Phytotherapy RTCs, 16 (18\%) about Laser therapy, 12 (13\%) Acupuncture and 2 (2\%) Homeopathy. On the other hand, 27 (30\%), 11 $(12 \%), 2(2 \%)$ and $1(1 \%)$ of RCTs with negative results were found for the use of Laser therapy, Phytotherapy, Acupuncture and Hypnosis in dental treatments, respectively (Figure 1).

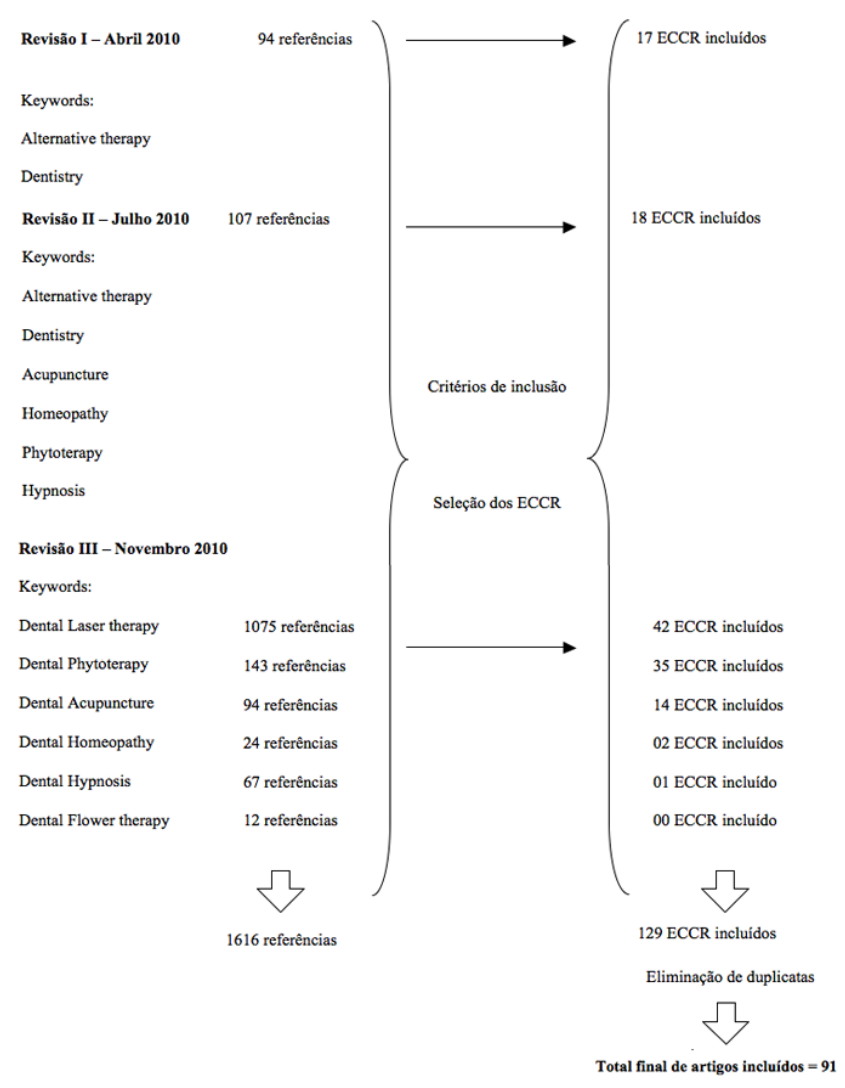

Figure 1 - Stages of the systematic literature search in PubMedMEDLINE.

After this, the RCTs were analyzed according to the type of CIP, area of knowledge of the periodical in which they were published and their Impact Factors (IF). It was observed that 59(64\%) of the studies were published in the dental area, with $9(10 \%)$ being published in journals with IF $\geq 3 ; 14(15 \%)$ with IF $\geq 2 ; 10$ (11\%) with IF $\geq 1$; $4(4 \%)$ with IF $<1$; and $22(24 \%)$ in dental periodicals without IF. Another $21(23,5 \%)$ RCT were published in specialized journals in the medical area, and as regards IF, were distributed in the following manner: $1(1 \%)$ IF $\geq 4 ; 3$ (3.5\%) IF $\geq 3 ; 6$ (7\%) IF $\geq 2 ; 7$ (8\%) IF $\geq 1 ; 2$ $(2 \%) \mathrm{IF}<1$ and $2(2 \%)$ without IF. In the periodicals classified as being in other areas of knowledge, $7(8 \%)$ of 
the total number of RCTs were published, and distributed as follows: $1(1 \%) \mathrm{IF} \geq 2 ; 3(3.5 \%) \mathrm{IF} \geq 1$ and $3(3.5 \%)$ $\mathrm{IF}<1$. Lastly, in periodicals in the area of complementary and alternative therapies 4 (4.5\%) RCTs were published, $1(1 \%)$ being in periodicals with IF $\geq 2$ and $3(3.5 \%)$ in $\mathrm{IF} \geq 1$ - Figure 2.

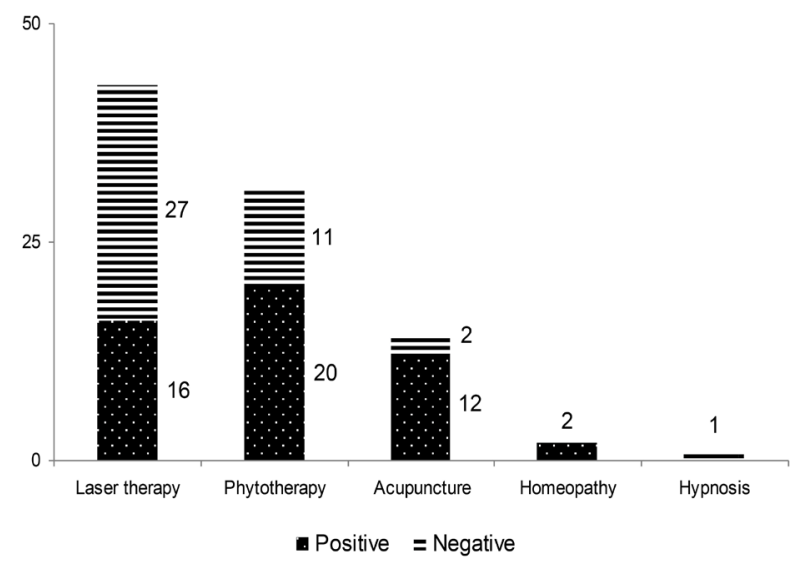

Figure 2 - Distribution of RCT according to the CIP modality and type of evidence presented.

The third analysis to which the $91 \mathrm{RCT}$ were submitted (Figure 3) relates to the CIP modality, type of evidence presented in the study and impact factor of the periodicals. Starting with the RCTs about Laser therapy it was shown that $16(17.5 \%)$ presented positive evidences, published in periodicals with IF $\geq 3(\mathrm{n}=3 ; 3.5 \%) ; \mathrm{IF} \geq 2(\mathrm{n}=8 ; 9 \%) ; \mathrm{IF} \geq 1(\mathrm{n}=4 ; 4 \%)$ and IF $<1(\mathrm{n}=1 ; 1 \%)$. Another $28(30 \%)$ RCTs that evaluated Laser therapy identified negative evidences, which were published in periodicals with: IF $\geq 3$ ( $\mathrm{n}=$ $5 ; 5.5 \%) ;$ IF $\geq 2(\mathrm{n}=6 ; 6.5 \%) ;$ IF $\geq 1(\mathrm{n}=8 ; 9 \%) ;$ IF $<$ $1(\mathrm{n}=3 ; 3,5 \%)$; and IF $=0(\mathrm{n}=5 ; 5.5 \%)$.

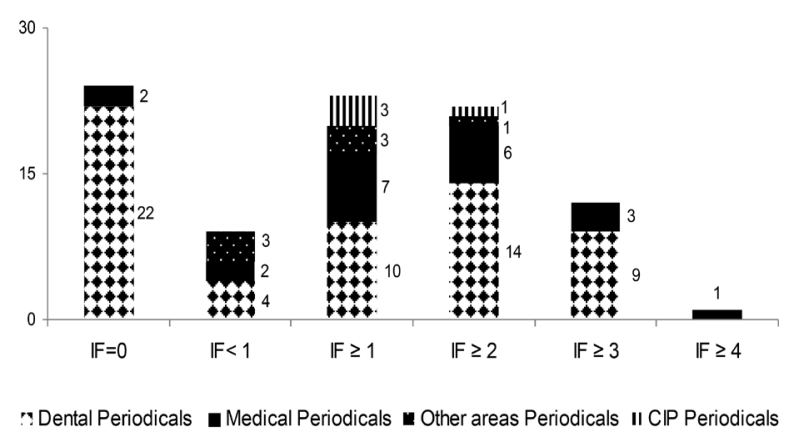

Figure 3 - Distribution of RCT according to area of knowledge and impact factor of the periodical.
RCTs that investigated the use of Phytotherapy in dentistry, classified according to the positive type of evidence and distributed according to the type of journals were distributed as follows: IF $\geq 4$ ( $\mathrm{n}=$ $1 ; 1 \%) ;$ IF $\geq 3(\mathrm{n}=2 ; 2 \%) ;$ IF $\geq 2(\mathrm{n}=5 ; 5.5 \%) ; \mathrm{IF} \geq 1$ $(\mathrm{n}=3 ; 5.5 \%) ; \mathrm{IF}<1(\mathrm{n}=1 ; 1 \%)$; and IF $=0(\mathrm{n}=8 ; 9 \%)$. As regards RCTs on Phytotherapy with negative evidences, these were as follows: IF $\geq 1(\mathrm{n}=1 ; 1 \%)$; IF $<1(n=2 ; 2 \%) ;$ IF $=0(n=8 ; 9 \%)$. Of the 14 RCTs that investigated the use of Acupuncture in dentistry, $12(13.5 \%)$ presented positive evidences, which were published in journals with the following impacts: IF $\geq$ $3(\mathrm{n}=1 ; 1 \%) ; \mathrm{IF} \geq 2(\mathrm{n}=3 ; 3.5 \%) ; \mathrm{IF} \geq 1(\mathrm{n}=3 ; 3.5 \%)$; IF $<1(n=2 ; 2 \%)$; and IF $=0(n=3 ; 3.5 \%)$. Of the two RCTs on Acupuncture that presented negative evidences, one $(1 \%)$ was published in a periodical with IF $\geq 3$ and one (1\%) with IF $\geq 1$.

In total only two RCTs were identified on the use of Homeopathy in dentistry, which presented positive evidence and were published in a periodical with IF $\geq$ 1. Only one RCT that investigated the use of Hypnosis in dentistry presented negative evidence and it also was published in a periodical with IF $\geq 1$.

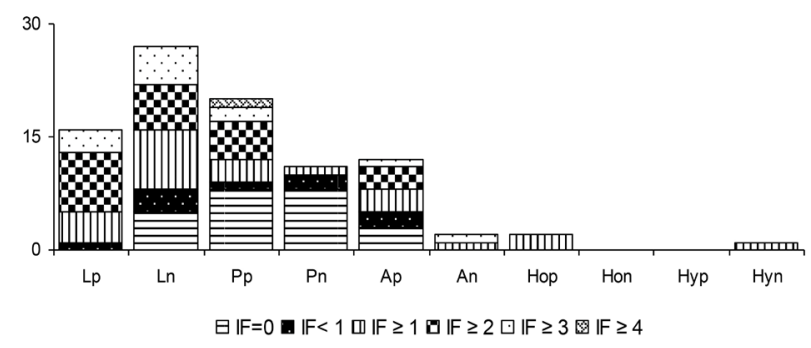

Figure 4 - Distribution of positive and negative RCT according to IF and CIP.

Legend: $\mathrm{Lp}=$ Laser therapy positive; $\mathrm{Ln}=$ Laser therapy negative; $\mathrm{Pp}=$ Phytotherapy positive; $\mathrm{Pn}=$ Phytotherapy negative; Ap = Acupuncture positive; An = Acupuncture negative; Hop = Homeopathy positive; Hon = Homeopathy negative; Нyp= Hypnosis positive; Hyp= Hypnosis negative.

\section{Discussion}

The aim of this SLR was to analyze the evidences about the use of CIP in dentistry, published over 
the last ten years, with the justification that this is a subject that has hardly been explored up to now. This study has the following limitations: scarcity of studies published about the subject; the quality of RCTs with an adequate description of the studied variables; the bibliographic survey conducted in only one database. However, the choice of PubMed-MEDLINE was made because of its broad scope in the area of health, the daily updates of bibliographic references and the thousands of publications indexed, with high impact on the international scientific community [26].

Ninety-one RCTs were selected by means of a bibliographic survey conducted in PubMedMEDLINE without restriction of language, and the predominance of the English language was verified, as with the exception of one single manuscript published simultaneously in English and German, all the other 90 were written in English.

When analyzing the $91 \mathrm{RCTs}$, it was found that $55 \%(\mathrm{n}=50)$ presented positive results and $45 \%$ $(n=41)$ negative results with regard to the use of complementary and alternative therapy in dentistry. This small predominance of positive evidences was verified in all the CIP modalities researched.

As regards the CIP modality of the RCT, a larger volume of publications on Laser therapy $(n=43$; $47 \%$ ) was observed, with predominance of negative evidences published in periodicals with $\mathrm{IF} \geq 1$; Phytotherapy ( $\mathrm{n}=31 ; 34 \%)$, with an equal number of positive and negative evidences published in FI = 0 ; and Acupuncture $(\mathrm{n}=14 ; 16 \%)$, also with a higher number of studies with positive evidences published in $\mathrm{IF}=0$ and $\mathrm{IF} \geq 2$.

According to Torlone and Riera [27] both the level of evidence and the methodological quality of the articles published are important aids in decisionmaking and affect the impact of the periodicals. In this respect, unconsciously, researchers and managers in the field of health can produce a bias in research because of the influence of the type of evidence and IF. Firstly, because searches for information initially tend to occur in journals of major impact and these tend to publish more investigations that present negative evidences in CIP [24]. Some authors reported that this phenomenon may occur in high impact journals due the fact these journals generally focus on publication of RCTs [28-32] guided by the biomedical perspective, and as this model does not adequately address the complexity of CIP interventions, the trend towards scarcity of these publications in high impact periodical persists.

In addition, according to Pinto [33], the IF value has been erroneously used as an instrument for evaluating the quality of scientific information or as an instrument for evaluating the production of courses and institutions [34]. Therefore, in the practice of evidence-based dentistry, care is recommended when interpreting the results of RCTs considered "favorable or unfavorable" for clinical use, particularly in the area of CIP, and specifically with regard to the IF of the periodical that published the study.

According to Hunt et al. [35], bias can also be produced by the difficulties in conducting studies about CIP using randomized and controlled research methodology, since this type of methodological design does not adequately contemplate the characteristics inherent to CIP. Furthermore, the type of periodical that publishes scientific evidences in the area of CIP could be a factor in the production of bias, in other words, journals specialized in CIP have a greater propensity to publish positive results produced by these therapies, whereas negative results are more likely to be published in a mainstream biomedical journal [36].

In the present SLR the major portion $(n=59 ; 64 \%)$ of RCTs were published in periodicals in the field of dentistry, and in these there was no predominance of positive or negative evidences. Nevertheless, among these studies the split mouth experimental design was outstanding; this consists of using arches, hemiarches, teeth and sites as experimental units, in which the patient exercises the function of being his/her own control.

According to Lesaffre et al. [37] these divisions provide the advantage of enabling a study to be conducted with a lower number of patients. On the other hand, two decades ago, the traps of this type of project were related in the literature on oral health. These reasons have generated frequent discussions about the quality of split mouth studies, particularly with regard to the establishment of safer and more efficient experimental elements that consider the individual as the experimental unit and its subdivisions $[3,38,39]$.

The citation of clinical significance and statistical significance has also been shown to be a polemic question to the extent to which these values may be interpreted in a confusing manner [40]. In this SLR $18 \%(\mathrm{n}=16)$ of the 91 RCTs cited both the clinical significance and statistical significance, among these there were 4.5\% $(n=4)$ RCTs on Acupuncture, 5.5\% $(\mathrm{n}=5)$ RCT on Phytotherapy and $8 \%(\mathrm{n}=7)$ RCT on Laser therapy.

According to Tulder et al. [41] the p-value is not 
very informative with reference to the effectiveness of the tested intervention, as it does not indicate whether the effect is clinically important, and only refers to the chance of the effect being observed. Clinical importance is defined as being the clinical difference observed between the studied groups, and for this reason, best represents the effectiveness of the tested intervention. Therefore, the larger portion of the RCTs in this SLR did not use these two types of significance, thus contributing to the difficulty of the study based on the practice of evidence-based dentistry.

We know that the results and conclusions of RSLs are directly affected by the studies included in it $[42,43]$. In this context, during the development of this research, we were faced with the difficulty of classifying some articles because the authors of these studies did not provide accurate data with reference to the $p$ value (the authors state only that the statistical analysis was conducted and that they found statistically significant results in a certain group). However, occurrence of this problem was very low $(n=2 ; 2 \%$ of the analyzed articles) and in such cases the classification of positive or negative evidence was made based only on the conclusion mentioned in manuscripts analyzed. We point out that for similar outcomes between the test group and control group, we classified the article as negative evidence [24].

We observed others obstacles with regard to the papers analyzed: the procedures for establishing a placebo group and the difficulties of blinding in CIP treatments. The literature reveals that in addition to the difficulties of identifying appropriate placebo interventions, some authors also reported the difficulties of randomizing and retaining patients in the CIP study $[44,45]$. The difficulty found with planning an RCT of CIPs relates directly to their rationality, because these practices includes an individualized approach in the diagnosis as well in the treatment of patients, and this conduct often represents part of the treatment [46].

In view of the considerations set out above, we believe that research can provide more consistent evidence of CIP when conducted by a combination of the quantitative method with qualitative method. This strategy has been recommended for studies that investigate more complex issues. Furthermore, the combination of the two methods promotes a considerable increase in the scientific value of RCTs [47-50], a situation that could facilitate the publication of studies on CIP in journals with higher IFs.

The findings of this SLR suggest that the production of knowledge about CIP in dentistry is at the initial stage, showing that evidences in this field are still not very well founded. On the other hand, it shows that the majority of the RCTs were published in periodicals in the area of dentistry, and this fact could be interpreted as a positive datum, bearing in mind that there are different stages of development between dentistry and other areas of knowledge in the field of health [38]. Due the difficulties and limitations reported in this SLR we emphasize that the results of this study should be interpreted with caution.

\section{Conclusions}

In this SLR, with the aim of analyzing evidences about the use of Acupuncture, Homeopathy, Phytotherapy, Hypnosis, Flower Therapy and Laser therapy in dentistry, it was concluded that although positive evidences were found for some of these therapies, they were limited with regard to their quality and consistency, thus fall short of the principles advocated by Evidence-Based Dentistry.

In addition, there was little difference between positive and negative evidences of the use of CIP in the field of dentistry, characterizing the low level of strength of evidence and consequently the low potential for clinical application, also in accordance with the principles of Evidence-Based Dentistry.

Finally, it was verified that there was little consistency with regard to the clinical use of CIP in dentistry, thus further investigations into the subject need to be developed, with particular attention being paid to the biases relative to research methodologies and the impact factor of periodicals.

\section{Conflict of interest}

The authors certify that there is no conflict of interest with any financial organization regarding the material discussed in the manuscript.

\section{AcKnowledgements}

This research was supported by "Fundação de Amparo à Pesquisa do Estado de São Paulo" (FAPESP) Process No. 2010/05217-0.

Financial Support

Sao Paulo State Foundation for Research Support - FAPESP (process 2010/05217-0). 


\section{References}

1. Connor LH. Relief, risk and renewal: mixed therapy regimens in an Australian suburb. Soc Sci Med 2004;59:695705.

2. Aakster CW. Concepts in alternative medicine. Soc Sci Med. 1986;22(2):265-73.

3. Harris P, Rees R. The prevalence of complementary and alternative medicine use among the general population: a systematic review of the literature. Complement Ther Med. 2000 Jun;8(2):88-96.

4. Clerici CA, Veneroni L, Giacon B, Mariani L, Fossati-Bellani F. Complementary and alternative medical therapies used by children with cancer treated at an Italian pediatric oncology unit. Pediatr Blood Cancer. 2009 Oct;53(4):599-604.

5. Obadia L. The Internationalisation and hybridization of medicines in perspective? Some reflections and comparisons between East and West. Transtext(e)s Transcultures [Internet]. 2009 May [cited 201 July 26]; [document 8 ] available from: $\mathrm{http}: / /$ transtexts.revues.org/index $276 . \mathrm{html}$

6. Hilsden RJ, Verhoef MJ, Rasmussen H, Porcino A, DeBruyn JC. Use of complementary and alternative medicine by patients with inflammatory bowel disease. Inflamm Bowel Dis.2011 Feb;17(2):655-62.

7. Spadacio C, Castellanos MEP, Barros NF, Monte Alegre S, Tovey P, Broom A. complementary and alternative medicines: a meta-synthesis. Cad. Saúde Pública [Internet]. 2010 Jan [cited 2010 mar 12]; 26(1): [about 7p.] available from http:www.scielo.br/pdf/csp/v26n1/02.pdf

8. Peters D, Chaitow L, Harris G, Morrison S. Integrative complementary therapies in primary care - a practical guide for health professionals. Churchill Livingstone, 2002.

9. McGuire MK, Newman MG. Evidence-based periodontal treatment-I.A estrategy for clinical decisions. Int J Periodontics Restor Dent 1995;15(1):70-83.

10. Rippon R, Gelbier S, Gibbons D. Evidence-based dentistry. Br Dent J 1996;180(5):169.

11. Akadiri OA, Adeyemo WL. Evidence-based dentistry in a developing economy - the nigerian example. Open Dent J. 2010 Jul 16;4:51-4.

12. Sutherland D. Evidence-based dentistry: Part V. Critical apprasial of the dental literature: papers about therapy. J Can Dent Assoc. 2001 Sep;67(8):442-5.

13. Wood L, Egger M, Gluud LL, Schulz KF, Jüni P, Altman DG, et al. Empirical evidence of bias in treatment effect estimates in controlled trials with different interventions and outcomes: meta-epidemiological study. BMJ. 2008 Mar 15;336(7644):601-5. Epub 2008 Mar 3.

14. Faggion Jr CM. Grading the quality of evidence and the strenght of recomendations in clinical dentistry: a critical review of 2 prominent approaches. J Evid Base Pract 2010;10:78-85.

15. CFO - Conselho Federal de Odontologia. Atos Normativos. Resolução CFO-82/2008. [cited 2011 July 26] Available from: http://cfo.org.br/servicos-e-consultas/atonormativo/?id=1282.

16. Beiki O, Beiki D. ParsMedline: establishment of a Webbased bibliographic database related to Iranian health and medical research. J Med Libr Assoc. 2005 July; 93(3):400-3.

17. Packer AL, Tardelli AO, Castro RCF. Public scientific knowledge distribution in health information, communication and information technology indexed in Med- line and Lilacs databases. Ciênc Saúde Coletiva [Internet]. 2007 May/Jun. [cited 2007]; 12(3): [about 12 p]. Avaible from: http://www.scielo.br/scielo.php?pid=s1413$81232007000300009 \&$ script $=$ sci arttext.

18. Hoong NK. Getting to know journal bibliographic databases. Singapore Med J 2010;51(10):757-60.

19. Nikolaos A P, Ioannidis JPA. The use of older studies in meta-analysis of medical interventions: a survey. Open Med. 2009; 3(2): e62-e68.

20. Journal of Young Investigators [internet]. Writing a literature review: preliminary research. In: Writing Scientific Manuscripts: a guide for undergraduates;, 2005. P.39. [cited 2012]. Avaible from: http://www.ptei.org/docs/Guide_to_Science_ Writing.pdf.

21. Biblioteca Virtual em Saúde (BVS). Descritores em Ciências da Saúde (DeCS). 2010 [cited 2011 July 26] Available from: http://decs.bvs.br/P/decsweb2010.htm

22. Evans D. Hierarchy of evidence: a framework for ranking evidence evaluating healthcare interventions. J Clin Nursing 2003;12:77-84.

23. American Dental Association (ADA). Clinical recommendations Handbook. 2011 [cited 2011 July 26] Available from: http://ebd.ada.org/contentdocs/FINAL_2011_Revised_ADA_Clinical_Recommendations_Handbook.pdf (Accessed on July 26, 2011).

24. Pittler MH, Abbot EF, Harkness EE. Location bias in controlled clinical trials of complementary/alternative therapies. J Clin Epidemiol. 2000 May;53(5):485-9.

25. Journal Citation Reports - JCR. 2009 [cited 2011 July 26] Available from: http://adminapps.isiknowledge.com/JCR/ JCR

26. Ontario Public Health Libraries. Using the PubMed Searches on the OPHS. [cited 2011 July 26]. Available from: http:// www.ophla.ca/pdf PubmedSearchesOPHS.pdf

27. Torloni MR, Riera MR. Design and level of evidence of studies published in two Brazilian medical journals recently indexed in the ISI Web of Science database. Sao Paulo Med J [Internet]. 2010 [cited 2010]; 128(4):[about 3p.]. Available from: http://www.scielo.br/scielo.php?pid=S151631802010000400005\&script $=$ sci arttext

28. Linde K, Ramirez G, Mulrow CD, Pauls A, Weidenhammer W, Melchart D. St John's wort for depression--an overview and meta-analysis of randomised clinical trials. BMJ. 1996 Aug 3;313(7052):253-8.

29. Moher D, Pham B, Lawson ML, Klassen TP. The inclusion of reports of randomised trials published in languages other than English in systematic reviews. Health Technol Assess. 2003;7(41):1-90.

30. Linde K, Streng A, Jürgens S, Hoppe A, Brinkhaus B, Witt $\mathrm{C}$, et al. Acupuncture for patients with migraine: a randomized controlled trial. JAMA. 2005 May 4;293(17):2118-25.

31. Bent S, Kane C, Shinohara K, Neuhaus J, Hudes ES, Goldberg $\mathrm{H}$, et al. Saw palmetto for benign prostatic hyperplasia. N Engl J Med. 2006 Feb 9;354(6):557-66.

32. Sood A, Knudsen K, Sood R, Wahner-Roedler DL, Barnes SA, Bardia A, et al. Publication bias for CAM trials in the highest impact factor medicine journals is partly due to geographical bias. J Clin Epidemiol. 2007 Nov;60(11):1123-6. Epub 2007 May 10.

33. Pinto LA. Cientometria: é possível avaliar qualidade da pesquisa? Scientia Medica, 2008;18(2):64-5.

34. Bicas HEA, Rother ET, Braga WER. Fatores de impacto, 
outros índices bibliométricos e desempenhos acadêmicos. Arq Bras Oftalmol. 2002;65:151-2.

35. Hunt K, Ernst E. Arch Dis Chil (2010). The evidence base for complementary medicine in children: a critial overview of systematic review. Arch Dis Child. 2011 Aug;96(8):76976. doi: 10.1136/adc.2009.179036. Epub 2010 Jul 6.

36. Shekelle PG, Morton SC, Suttorp MJ, Buscemi N, Friesen C. Challenges in systematic reviews of complementary and alternative medicine topics. Ann Intern Med. 2005 Jun 21;142(12 Pt 2):1042-7.

37. Lesaffre E, Garcia Zattera M-J, Redmond C, Huber H, Needleman I. Reported methodological quality of splitmouth studies. J Clin Periodontol 2007;34:756-61. doi:10.1111/j.1600-051X.2007.01118.x.

38. Susin C, Rosing CK. Praticando a odontologia baseada em evidências. Canoas: ULBRA, 1999.

39. Lesaffre E, Philstrom B, Needleman I, Worthington H. The design and analysis of splitmouth studies: what statisticians and clinicians should know. Stat Med. 2009 Dec 10;28(28):3470-82.

40. Kraemer HC, Morgan GA, Leech NL, Gliner JA, Vaske JJ, Harmon RJ. Measures of clinical significance. J Am Acad Child Adolesc Psychiatry. 2003 Dec;42(12):1524-9.

41. Tulder M, Malmivaara A, Hayden J, Koes B. Statistical significance versus clinical importance: trials on exercise therapy for chronic low back pain as example. Spine (Phila Pa 1976). 2007 Jul 15;32(16):1785-90.

42. Hunt K, Ernst E. The evidence-base for complementary medicine in children: a critical overview of systematic reviews. Arch Dis Child. 2011 Aug;96(8):769-76. doi: 10.1136/ adc.2009.179036. Epub 2010 Jul 6.

43. Pádula RS, Pires RS, Alouche SR, Chiavegato LD, Lopes $\mathrm{AD}$, Costa LOP. Análise da apresentação textual de revisões sistemáticas em fisioterapia publicadas no idioma português. Rev Bras Fisio. 2012;16(14):281-8.

44. Nahin R, Straus S. Research into complementary and alternative medicine: problems and potential. BMJ. 2001 January 20;322(7279):161-164.

45. Tamayo C, Boon H, Ghishan F, Trinh K. Research methodology: evaluating complementary and alternative therapies. Drug Information J. 2002; 36:535-48.

46. Baranowsky J, Klose P, Musial F, Häuser W, Dobos G, Langhorst J. Qualitative systemic review of randomized controlled trials on complementary and alternative medicine treatments in fibromyalgia. Rheumatol Int. 2009 Nov;30(1):1-21. doi: 10.1007/s00296-009-0977-5. Epub 2009 Aug 12.

47. Grissmer DW, Subotnik RF, Orland M. A guide to incorporating multiple methods in randomized controlled trials to assess intervention effects. Washington, DC: American Psychological Association, 2009.

48. Verhoef MJ, Casebeer AL, Hilsden RJ. Assessing efficacy of complementary medicine: adding qualitative research methods to the "Gold Standard". J Alternative and Complementary Med. June 2002;8(3):275-81. doi:10.1089/10755530260127961.

49. Deng GE, Frenkel M, Cohen L, Cassileth BR, Abrams DI, Capodice JL, et al. Evidence-based clinical practice guidelines for integrative oncology: complementary therapies and botanicals. J Soc Integr Oncol. 2009 Summer;7(3):85-120.

50. Verhoef MJ, Leis A. From studying patient treatment to studying patient care: arriving at methodologic crossroads. Hematol Oncol Clin North Am 2008;22:671-82, viii-ix.
Received: $2012-11-26$

Accepted: $2013-2$ - 21

\section{Corresponding Author}

Camila da Silva Gonçalo

Faculty of Medical Sciences (FCM)

Department of Community Health

Endereço: Rua: Tessália Vieira de Camargo, 126

Cidade Universitária "Zeferino Vaz" - Campinas - SP - Brasil -

CEP: $13083-887$

E-mail: camilagoncalo@gmail.com 